\title{
Novel Monoclonal Antibody mAb G3A5 Recognizes 138-kDa Glyocoprotein Localized on the Golgi Membrane
}

\author{
Teruo Yamauchi, Masahito Higashiura and Tatsuo Yagura ${ }^{\dagger}$ \\ Department of Biology, Faculty of Science, Kwansei Gakuin University, Nishinomiya, Japan
}

Key words: monoclonal antibody/Golgi apparatus/glycoprotein

\begin{abstract}
Partially purified Golgi membranes of HeLa cells were used as antigen to produce a novel monoclonal antibody (mAb G3A5). The mAb G3A5 specifically labeled Golgi apparatus of human and monkey cultured cells as ascertained by indirect immunofluorescence but did not stain those of bovine or mouse cells. Treatment with nocodazole and brefeldin A (BFA) induced fragmentation and redistribution of the staining. Western immunoblot analysis showed that $\mathrm{mAb}$ G3A5 was directed against a single polypeptide with an apparent molecular mass of 138-kDa (p138 antigen). The p138 antigen is an integral membrane protein of the Golgi apparatus, as assessed by several assays: protease protection, salt wash and flotation in sucrose density gradient centrifugation. The p138 antigen was purified using immunoaffinity chromatography. The apparent molecular mass of the p138 antigen decreased by 2 to $4 \mathrm{kDa}$ after treatment with the peptide: $\mathrm{N}$-glycosidase $\mathrm{F}$, while digestion with ENDO F or Neuraminidase did not have this effect. Thus, p138 antigen is a glycoprotein containing asparaginelinked carbohydrates.
\end{abstract}

The Golgi apparatus is a unique cytoplasmic organelle of most eukaryotic cells that functions as the processing and sorting center for secretory, plasma membrane and lysosomal proteins. The Golgi apparatus is composed of at least four distinct compartments, namely the cis, medial and trans Golgi cisternae, plus the trans Golgi network, usually localized in the perinuclear region of a cell. Distinct functional properties have been ascribed to this stack of cisternae (1), and many of the enzymes involved in Golgi functions as well as the proteins constituting carrier vesicles which mediate membrane traffic are progressively being characterized $(2,3)$. Still, little is known about the structural aspect of the integral portion of the Golgi stack. One reason for this is the difficulty in obtaining pure preparations of the Golgi stack by conventional fractionation procedures based on centrifugation techniques. To circumvent these difficulties, several approaches using specific antibodies were examined as a means of studying resident proteins of the Golgi stack apparatus (4-15). One of these proteins has already been identified as an essential enzyme for the biosynthesis of glycoproteins (16).

In the present study we describe the production of a monoclonal antibody against the Golgi apparatus (mAb G3A5) along with characteristics of its novel antigen

\footnotetext{
$\dagger$ To whom correspondence should be addressed.

Abbreviations: $\mathrm{KPO}_{4}$, potassium-phosphate buffer; BFA, brefeldin A; WGA, wheat germ lectin.
}

protein.

\section{MATERIALS AND METHODS}

Cells. Human lung fibroblast TIG-3 and bovine epithelial cells CKT-1 were obtained from the Japan Cancer Research Resources Bank. TIG-3, CKT-1, SV40 transformed monkey kidney cells COS-7, and mouse fibroblasts $\mathrm{C} 3 \mathrm{H} 2 \mathrm{~K}$ were grown in Eagle's minimum essential medium supplemented with $10 \%$ fetal calf serum. HeLa cells were grown in the same medium supplemented with $5 \%$ calf serum.

Preparation of microsomal fractions from HeLa cells. HeLa cells were harvested from culture plates, washed once with phosphate buffered saline and then with buffer A ( $20 \mathrm{mM}$ Tris-HCl, pH 7.5, $1 \mathrm{mM} \mathrm{MgCl}_{2}, 250 \mathrm{mM}$ sucrose). The cell pellets $(2 \mathrm{~g})$ were next suspended in $6 \mathrm{ml}$ of buffer $\mathrm{A}$ and homogenized with a Potter homogenizer. The homogenate was centrifuged at $600 \times \mathrm{g}$ for $5 \mathrm{~min}$ to separate out unbroken cells and nuclei (nuclear pellet). The supernatant (post-nuclear fraction) was then centrifuged at $7,000 \times \mathrm{g}$ for $10 \mathrm{~min}$. The supernatant obtained (post-mitochondrial fraction) was further centrifuged at $100,000 \times \mathrm{g}$ for $1 \mathrm{~h}$, resulting in pellets which were the microsomal fraction (Golgi rich fraction). These were used for immunizing the mice.

Antibody production. Microsomal fractions as antigen were prepared as described above. Hybridoma cell lines secreting monoclonal antibodies against the Golgi apparatus were prepared by the method described in our previous work (17). $\mathrm{BALB} / \mathrm{c}$ mice were immunized with three IP injections of the 
microsomal fraction (50 $\mu \mathrm{g}$ protein) which had been sonicated and precipitated in alumina gels. The immunized mice were finally boosted by injecting intraperitoneally with the microsomal fraction ( $50 \mu \mathrm{g}$ of protein) without alumina. On the third day, their spleen cells were fused with P3X63Ag8-653 mouse myeloma cells, and hybridoma cells recovered from positive wells were cloned three times by limiting dilution. The hybridoma clones were injected into pristane-primed $\mathrm{BALB} / \mathrm{c}$ mice to obtain ascitic fluid.

The resulting monoclonal antibody in ascitic fluid was purified by Affi-Gel Protein A MAPS II according to the manufacturer's instruction (Bio-Rad) and its type was determined using Mouse Monoclonal Antibody Isotyping Kit (Amersham).

Immunofluorescence. Cells were grown on glass coverslips and prepared for immunofluorescence in several different ways. The method of fixation that worked best for our monoclonal antibody was immersion of slips in acetone for $10 \mathrm{~min}$ at $-20^{\circ} \mathrm{C}$ followed by air drying. After washing with PBS, cells were treated with $1 \%$ Triton X-100 in PBS for $10 \mathrm{~min}$. The fixed and permeated cells were next incubated with 50 $\mu \mathrm{g} / \mathrm{ml}$ purified monoclonal antibody for $60 \mathrm{~min}$ at room temperature, washed with PBS, and then incubated with affinitypurified fluorescein rabbit anti-mouse IgG (Cappel).

The preparations were treated with $0.05 \mu \mathrm{g} / \mathrm{ml}$ of the DNA stain Hoechst 33258 prior to mounting so that nuclei could be visualized with appropriate filter combinations.

Western immunoblot. Immunoblots were prepared by electrophoresing protein samples on minigels, transferring them to PVDF-membrane, and labelling them with antibody and BCNP/NBT as described previously (18).

Trypsin treatment. Protease treatment of microsomal fractions was performed according to Burke et al. (4). In brief, the microsomal membrane fractions $(5 \mathrm{mg} / \mathrm{ml}$ protein in $10 \%$ sucrose, $5 \mathrm{mM}$ HEPES-KOH, pH 7.0, $1 \mathrm{mM} \mathrm{MgCl}_{2}$ ) were incubated with DPCC-trypsin (Sigma) for $1 \mathrm{~h}$ at $25^{\circ} \mathrm{C}$ in the presence or absence of $0.4 \%$ Triton $\mathrm{X}-100$. The reaction was terminated by the addition of $0.5 \mathrm{ml}$ of $10 \%$ trichloroacetic acid. Acid precipitated materials were made soluble and neutralized by the addition of $15 \mu \mathrm{l}$ of $1 \mathrm{M}$ Tris, $\mathrm{HCl}$, pH 9.5 . After boiling for $5 \mathrm{~min}$, the samples were applied to a $7.5 \%$ polyacrylamide SDS gel and immunoblotted with the mAb G3A5.

Mannosidase II enzyme assay. The activity of mannosidase II was assayed by measuring the hydrolysis of $p$-nitrophenyl $\alpha$-D-mannopyranoside as described by Tulsiani et al. (19).

Immunoaffinity purification of the p138 antigen. For purification, microsomal fractions prepared as described above, from $1 \times 10^{12} \mathrm{HeLa}$ cells were solubilized with Triton X-100
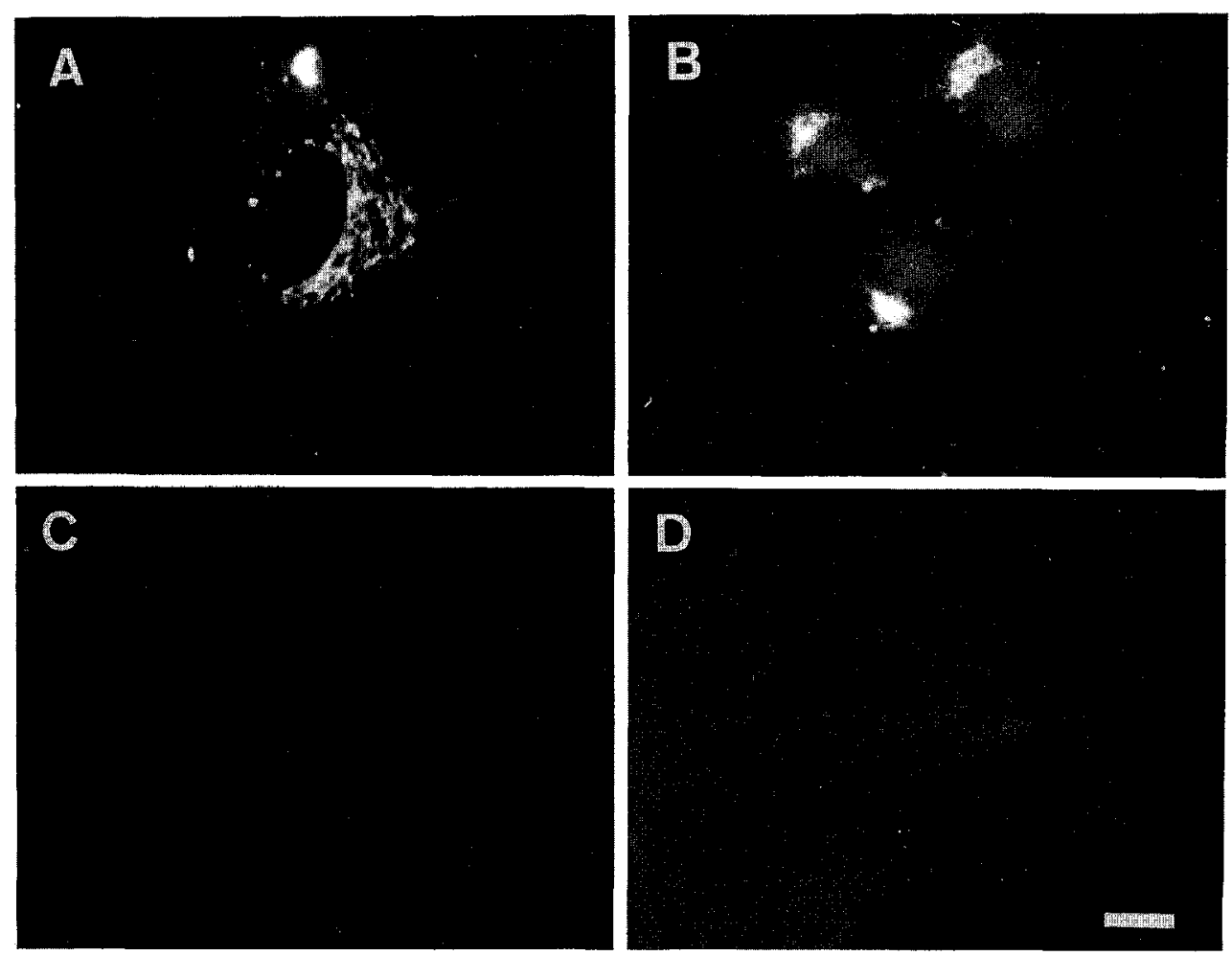

Fig. 1. Immunofluorescent staining by the mAb G3A5 of human fibroblasts TIG (A), SV40 transformed monkey kidney cells COS-7 (B), mouse fibroblasts $\mathrm{C} 3 \mathrm{H} 2 \mathrm{~K}(\mathrm{C})$ and bovine kidney epithelial cells CKT-1 (D). Note intense staining in the perinuclear cytoplasm of human fibroblasts (A) and mouse cells (B). Bar, $10 \mu \mathrm{m}$. 
containing buffer $\mathrm{B}(10 \mathrm{mM}$ Tris- $\mathrm{HCl}, \mathrm{pH} 7.6,0.5 \mathrm{M} \mathrm{NaCl}, 1$ $\mathrm{mM} \mathrm{MgCl}_{2}, 1 \%$ Triton X-100, $1 \mathrm{mM}$ PMSF, $5 \mu \mathrm{g} / \mathrm{ml}$ each of leupeptin (Sigma), pepstatin A (Sigma) and chymostatin (Sig$\mathrm{ma}), 2.5 \mu \mathrm{g} / \mathrm{ml}$ antipain (Sigma)). After centrifugation at $100,000 \times \mathrm{g}$ for $1 \mathrm{~h}$ to remove insoluble materials, the sample was mixed with mAb G3A5-antibody Sepharose $(1.5 \mathrm{~g}$ of original dry weight bound with $10 \mathrm{mg}$ of antibody) and incubated for $8 \mathrm{~h}$ at $4^{\circ} \mathrm{C}$ with rotation. The Sepharose was then poured into a column, and washed successively with $50 \mathrm{ml}$ of $20 \mathrm{mM}$ Tris- $\mathrm{HCl}, \mathrm{pH} 7.6,0.5 \mathrm{M} \mathrm{NaCl}, 0.5 \%$ Triton $\mathrm{X}-100$ and then with $50 \mathrm{ml}$ of the same buffer reducing the concentration of Triton X-100 to $0.1 \%$. The proteins were eluted with $20 \mathrm{mM}$ Tris, 50\% ethyleneglycol, $0.1 \mathrm{mM}$ EDTA and $1 \mathrm{mM}$ betamercaptoethanol, $\mathrm{pH}$ 11.5. One-ml portions were collected in tubes containing $0.1 \mathrm{ml}$ of $1 \mathrm{M}$ Tris- $\mathrm{HCl}, \mathrm{pH} 6.8$ and were frozen for later use.

Glycosidase digestions. The p138 antigen used for glycosi-

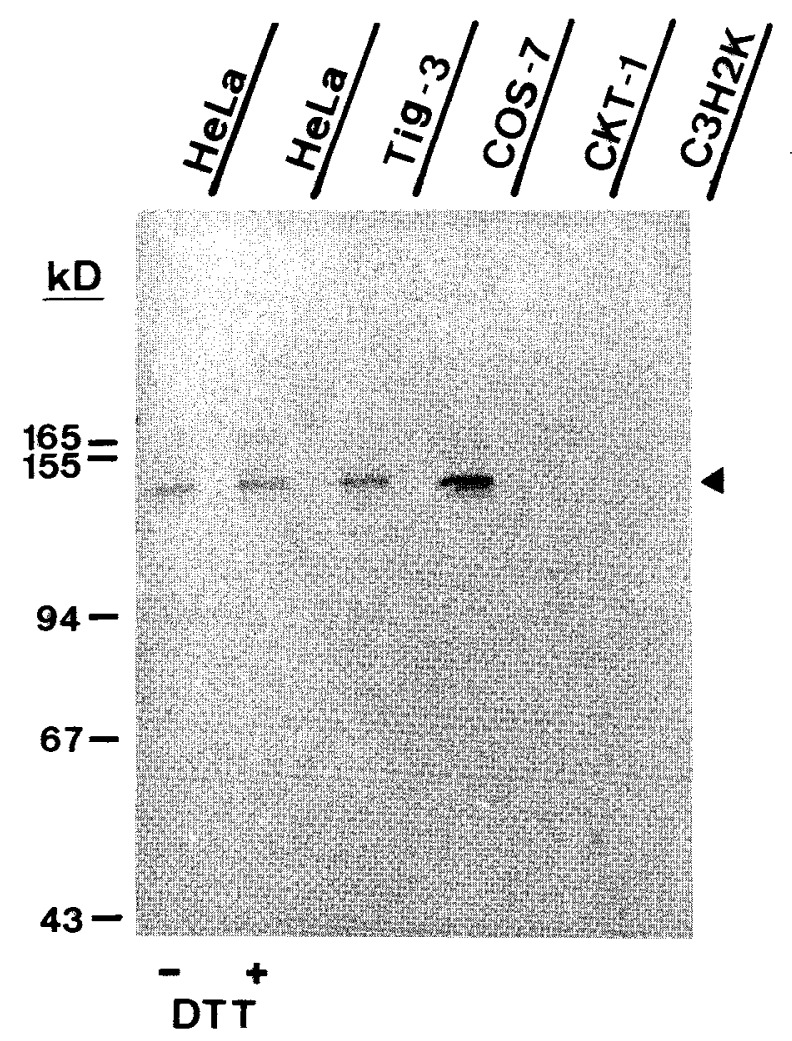

Fig. 2. Identification by western immunoblotting of the antigen recognized by mAb G3A5.

The cell extracts were boiled for $5 \mathrm{~min}$ in the presence of SDS and dithiothreitol (DTT) and run in 10\% SDS-PAGE. One sample for HeLa (DTT, - ) was boiled with SDS in the absence of DTT. After transfer from the gel, the antigen was reacted with $\mathrm{mAb}$ G3A5 followed by alkaline phosphatase conjugated rabbit anti-mouse IgG antibody. Molecular weights of standards run in parallel are given in kDa. In human (HeLa and TIG-3) and monkey (COS-7) cells the whole cell extracts show a single $138 \mathrm{kDa}$ band. The molecular mass of the antigen was the same for extracts of HeLa cells prepared in either the presence or absence of DTT. dase digestion experiment was purified by immunoaffinity chromatography. N-glycosidase F, ENDO H, ENDO F and Neuraminidase (Boehringer Mannheim) digestions were carried out as described previously (15, 20-22).

Ion exchange column chromatography. All steps were performed at $0-4^{\circ} \mathrm{C}$. Post-nuclear supernatants were prepared as described above from $1 \times 10^{9} \mathrm{HeLa}$ cells. To the fraction was added 0.1 vol. of $5 \mathrm{M} \mathrm{NaCl}$ and 0.01 vol. of $10 \%$ Triton $\mathrm{X}$ -
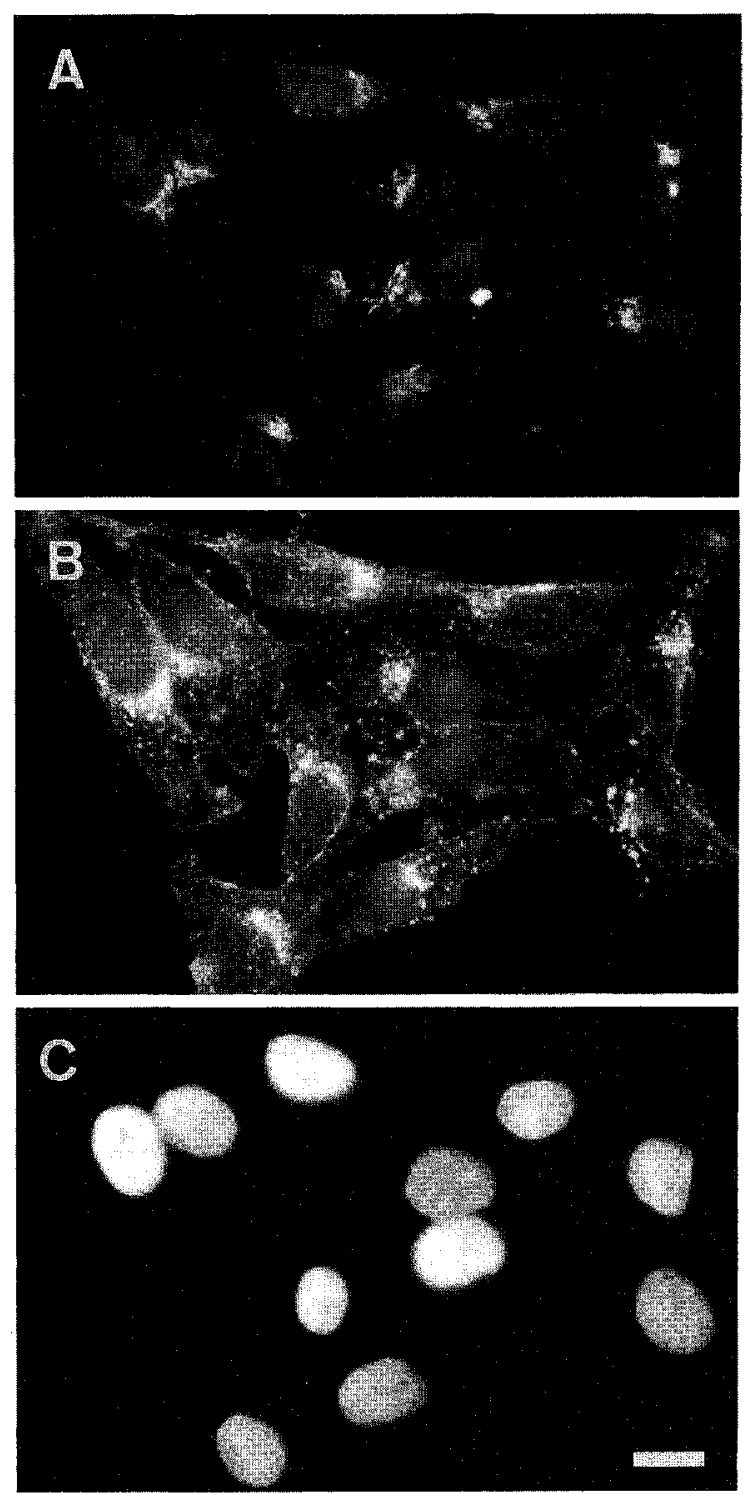

Fig. 3. The Golgi apparatus in HeLa cells stained by mAb G3A5. $\mathrm{HeLa}$ cells were processed for immunofluorescence staining with mAb G3A5 and later stained with TRITC-conjugated wheat germ lectin, WGA (Sigma) $(20 \mu \mathrm{g} / \mathrm{ml})$ and Hoechst $33258(0.5 \mu \mathrm{g} / \mathrm{ml})$. The reticular network revealed by indirect immunofluorescence labeling (A) is clearly evident in the Golgi apparatus located in the perinuclear region as shown by the corresponding WGA stained (B) and Hoechst DNA stained (C) pictures of the same cells. Bar, $10 \mu \mathrm{m}$. 
100 , and it was left for $1 \mathrm{~h}$ with stirring. After centrifugation at $10,000 \times \mathrm{g}$ for $1 \mathrm{~h}$, the supernatants were divided into two parts. Each part was dialyzed to buffer D (20 mM potassiumphosphate buffer $\left(\mathrm{KPO}_{4}\right), \mathrm{pH} 7.2,50 \mathrm{mM} \mathrm{NaCl}, 0.3 \%$ Triton $\mathrm{X}-100$ ) or buffer $\mathrm{E}$ (50 mM Tris- $\mathrm{HCl}, \mathrm{pH} 7.2,1 \mathrm{mM} \mathrm{MgCl}$, $0.3 \%$ Triton $\mathrm{X}-100$ ) for DEAE-Sephacel or hydroxylapatite column chromatography, respectively. Both column chromatographies were performed essentially as described by Tulsiani et al. $(19,23)$.

\section{RESULTS}

Monoclonal antibody. Those hybridoma clones producing monoclonal antibody against the Golgi apparatus were selected from hybridized spleen cells prepared from mice immunized with the Golgi rich fractions. Subsequent screening of monoclonal antibody was performed by indirect immunofluorescence assay using HeLa cells fixed-permeabilized with acetone. One hybridoma clone, G3A5 hybridoma, produced a monoclonal antibody (mAb G3A5) bound to the perinuclear region of human fibroblasts (TIG-3) (Figs. 1A) and monkey cells (Cos 7) (Fig. 1B), but not to those of mouse $(\mathrm{C} 3 \mathrm{H} 2 \mathrm{~K})$ or calf $(\mathrm{CKT}-1)$ cells (Figs. $1 \mathrm{C}$ and 1D). The same staining characteristic was obtained for preparations fixed with paraformaldehyde and permeabilized with methanol. These results suggested that the epitope of antigen recognized by mAb G3A5 was unique for primate cells and then the antibody did not cross-react with homologous protein from the species classified in the other orders. The mAb G3A5 was classified as an $\operatorname{IgG}_{1}$.

The $m A b G 3 A 5$ recognized a $138-k D a$ protein. The antigen recognized by $\mathrm{mAb}$ G3A5 was identified by western immunoblot analysis. Total cell extracts from human, monkey, bovine and mouse cells were subjected to SDS-PAGE, then the proteins were transferred to a PVDF membrane and immunoblotted with the $\mathrm{mAb}$. Figure 2 shows that a band of $138-\mathrm{kDa}$ (p138 antigen) was detected in each lane of human (fibroblasts and HeLa) and mónkey (Cos-7), but not of bovine (CKT-1) or mouse $(\mathrm{C} 3 \mathrm{H} 2 \mathrm{~K})$. Inability of $\mathrm{mAb}$ to detect a $138-$ $\mathrm{kDa}$ protein from bovine or mouse cells coincided with absence of immunofluorescence on these cell types
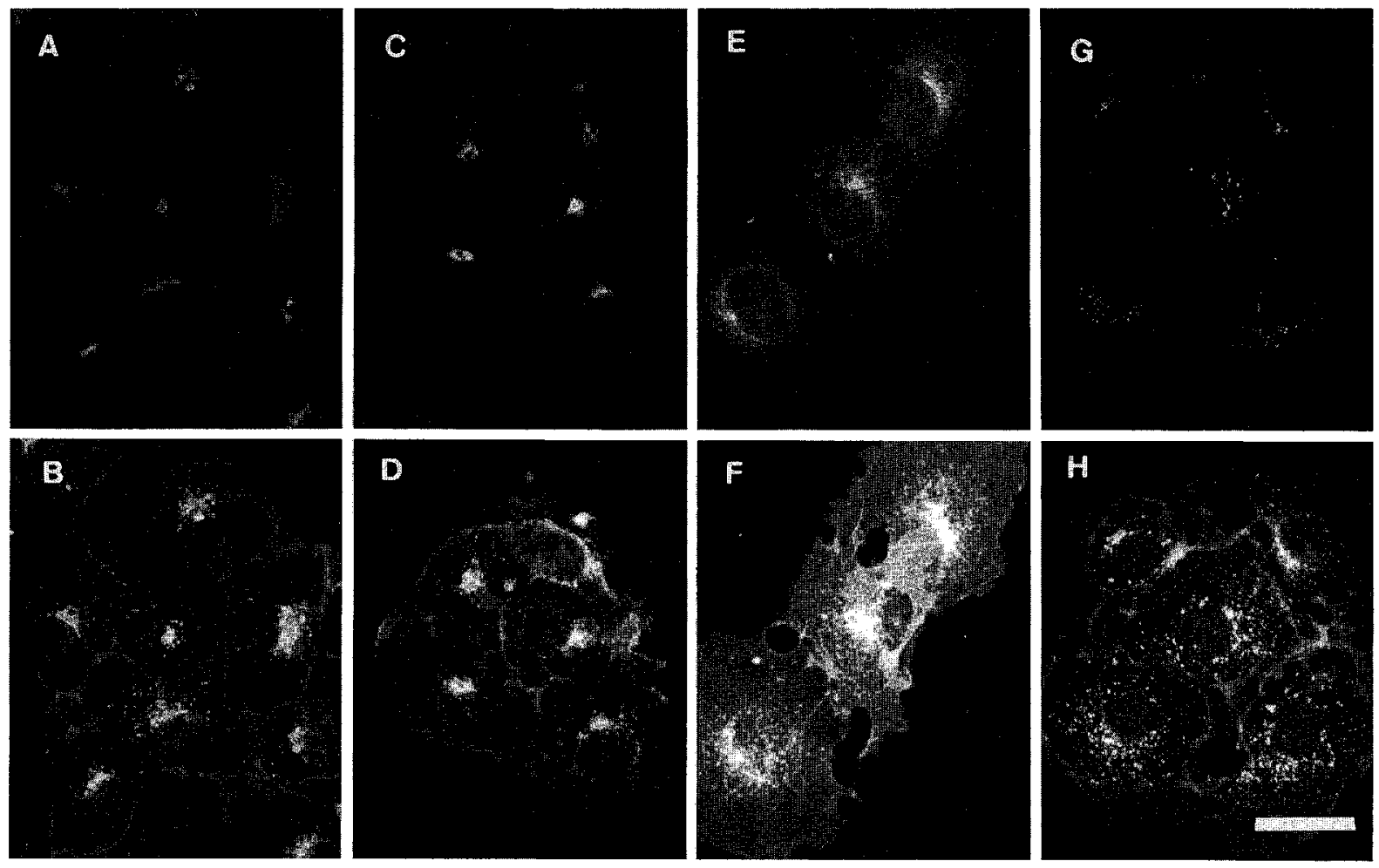

Fig. 4. Influence of nocodazol or BFA on distribution of mAb G3A5 staining and morphology of the Golgi apparatus.

COS-7 cells were incubated with normal medium (A and B), or $2 \mu \mathrm{g} / \mathrm{ml} \mathrm{BFA}$ for $2 \min (\mathrm{C}$ and D), or for $45 \min (\mathrm{E}$ and $\mathrm{F}$ ) or $10 \mu \mathrm{M}$ nocodazol for $45 \mathrm{~min}(\mathrm{G}$ and $\mathrm{H})$. The cells were then fixed, permealized with acetone, and labeled with mAb G3A5 followed by FITC-conjugated rabbit anti-mouse IgG. After washing, the cells were incubated with TRITC-conjugated WGA. After a final wash, the cells were prepared for microscopy. Cells were photographed in fluorescein (A, C, E, G) and TRITC (B, D, F, H) optics to identify mAb G3A5 and WGA binding, respectively. The WGA photographs were sometimes contaminated with cell surface lectin binding sites. Bar, $20 \mu \mathrm{m}$. 
shown in Figs. 1C and 1D. Thus, mAb G3A5 recognized an epitope common to a 138 -kDa protein from primate cells only. Apparent molecular mass of the p138 antigen on SDS-PAGE did not change when extracts were boiled in the presence or absence of reducing agent, dithiothreitol (Fig. 2), suggesting that the p138 antigen does not exist as a disulfide-linked multimer.

Localization of p138 antigen to the Golgi apparatus. By immunofluorescence, the mAb G3A5 staining revealed lamellar and network structures (Figs. 1A and 1B), which are characteristic of the Golgi apparatus (24, $25)$. The association of the p138 antigen with the Golgi apparatus was further investigated with double staining using wheat germ lectin (WGA). WGA can be used as a Golgi marker because it binds to sugars that are added to glycoproteins in the Golgi apparatus. Fig. 3 shows that WGA staining gave the same perinuclear staining (B) as that observed with the mAb G3A5 (A) in HeLa cells. This result suggests that the perinuclear staining with the mAb G3A5 corresponded to the Golgi apparatus.

Next, supporting evidence for the localization of the p138 antigen to the Golgi apparatus was obtained from changes in localization in response to BFA and nocodazole treatment. BFA is known to induce a redistribution of Golgi proteins into the endoplasmic reticulum (2629 ) by inhibiting vesicular transport from the endoplasmic reticulum $(30,31)$. The drug nocodazole disrupts

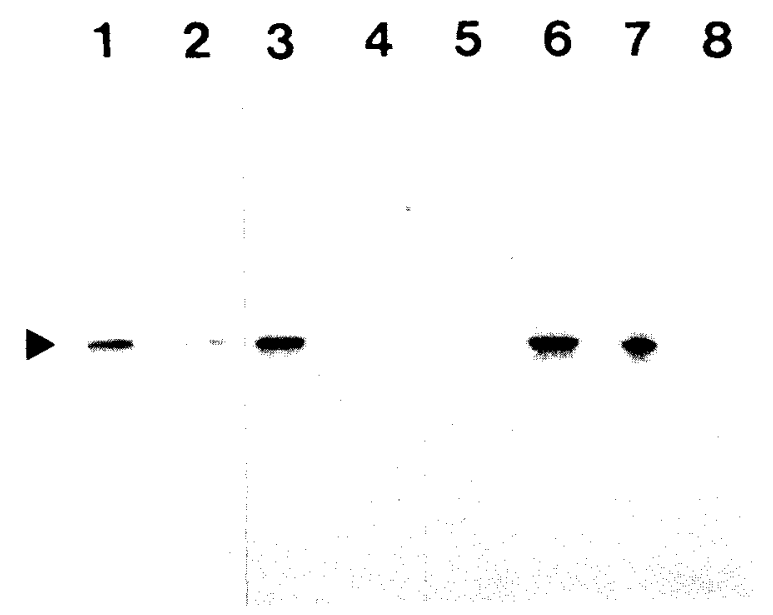

Fig. 5. Distribution of the p138 antigen in subcellular fractions prepared from HeLa cells.

HeLa cell fractionation was performed as described in Materials and Methods, and fractions were western immunoblotted with $\mathrm{mAb}$ G3A5. (Lane 1) Post nuclear supernatant; (lane 2) nuclear pellet; (lane 3) post mitochondrial supernatant; (lane 4) mitochondrial pellet; (lane 5) 100,000 $\times \mathrm{g}$ supernatant; (lane 6) 100,000 $\times \mathrm{g}$ pellet (microsomal fraction); (lane 7) $100,000 \times \mathrm{g}$ supernatant after the addition of Triton $\mathrm{X}-100$ and $\mathrm{NaCl}$ (final concentrations were $1 \%$ and $0.5 \mathrm{M}$ ); (lane 8 ) $100,000 \times \mathrm{g}$ pellet of the lane 7 . Arrow head, $138-\mathrm{kDa}$. cytoskelton microtubules inducing the Golgi apparatus to move away from the nuclear region through the cytoplasm $(32,33)$. The effect of BFA on the distribution of the staining of Cos-7 cells by the mAb G3A5 was first examined. Fig. 4E shows that the staining was dispersed through the cytoplasm after a 45 min treatment of COS cells with BFA, while short term treatment $(2 \mathrm{~min})$ did not change the localization of p138 antigen (Fig. 4C). Next, when cells were incubated with nocodazole for $45 \mathrm{~min}$, peripheral staining with mAb G3A5 appeared disintegrated and dispersed through the cytoplasm as fragments (Fig. 4G). Also, the Golgi apparatus as represented by WGA, showed the same redistribution as that with $\mathrm{mAb}$ G3A5 staining (Figs. $4 \mathrm{D}, \mathrm{F}$, and $\mathrm{H}$ ).

p138 antigen in subcellular fractions of HeLa cells. The pattern of immunofluorescence staining with $\mathrm{mAb}$

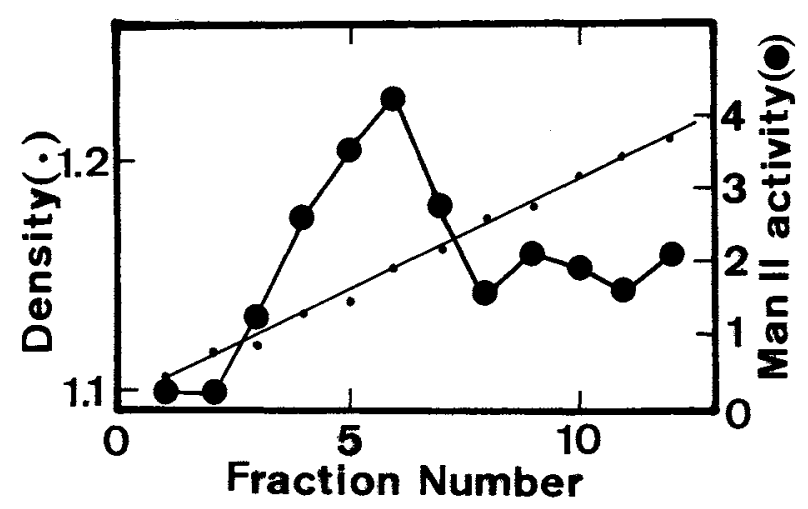

C 1 5 10

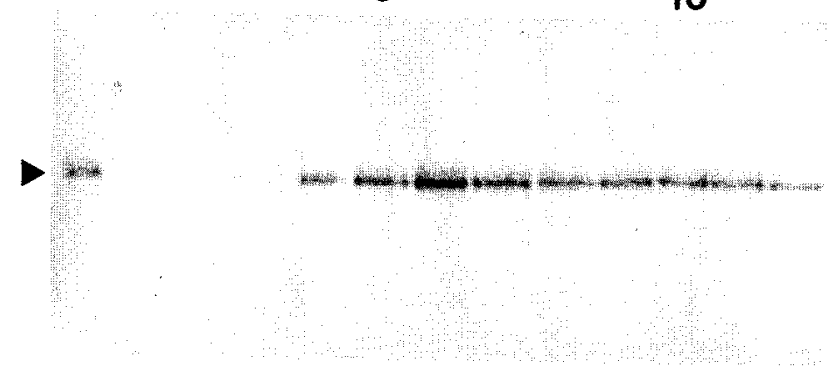

Fig. 6. Subfractionation of microsomes by equilibrium density centrifugation.

Microsomal membranes in $100,000 \times \mathrm{g}$ pellet fraction (see Fig. 5) were separated by flotation in $20-45 \%$ sucrose gradient according to the method described by Brown and Farquhar (10). The 100,000 $\times \mathrm{g}$ pellet microsomal fractions from $8 \times 10^{8} \mathrm{HeLa}$ cells were resuspended in buffer $\mathrm{C}(1 \mathrm{ml}$ of $1 \mathrm{mM}$ Tris-HCl, pH 7.6, $1 \mathrm{mM}$ EDTA, 50\% (w/w) sucrose) with a Dounce homogenizer. The sample placed in a centrifuge tube was overlayed with a sucrose gradient in the above buffer and spun at $150,000 \times \mathrm{g}$ for $8 \mathrm{~h}$ in a Hitachi RP-55S rotor (Hitachi Co.). $140 \mu \mathrm{l}$ portions for each tube were collected from the bottom. (Upper graph) $\alpha$-D-Mannosidase II activity and density of sucrose $(\mathrm{g} / \mathrm{ml})$; (Lower panel) western immunoblotting of each fraction with mAb G3A5. (c) indicates the microsomal fraction (control). Arrow head, 138-kDa. 
G3A5 and the effect of the two drugs on p138 antigen distribution clearly demonstrate that the antigen is localized within the Golgi apparatus. To examine it further, we studied subcellular localization of the p138 antigen by fractionation of subcellular organella. Fig. 5 shows that the p138 antigen did not precipitate with the nuclear fraction, but was recovered in the precipitates after centrifugation at $100,000 \times \mathrm{g}$ of post mitochondrial supernatants. The $100,000 \times \mathrm{g}$ pellets represented the microsomal fraction. The $100,000 \times \mathrm{g}$ microsomal fraction was next separated by flotation in sucrose density gradient centrifugation (Fig. 6). The p138 antigen was found in fractions overlapping a peak of $\alpha$-D-mannosidase II activity $(\rho=1.15 \mathrm{~g} / \mathrm{ml})$. As $\alpha$-D-mannosidase II is known to be a Golgi enzyme localized in medial-Golgi cisternae (34), a concentration of the p138 antigen in light Golgi subfractions corresponding to medial Golgi elements was suggested.

To study the topology and potential transmembrane disposition of the p138 antigen, two experiments were carried out: a protease protection experiment and a salt extraction procedure $(35,36)$. Microsomal fractions prepared from HeLa cells as described above were used. As shown in Fig. 7, the protease protection experiments carried out in the presence or absence of detergent, Triton $\mathrm{X}-100$, suggested that the $\mathrm{p} 138$ antigen was localized on the luminal side of the Golgi membrane. The p138 anti-

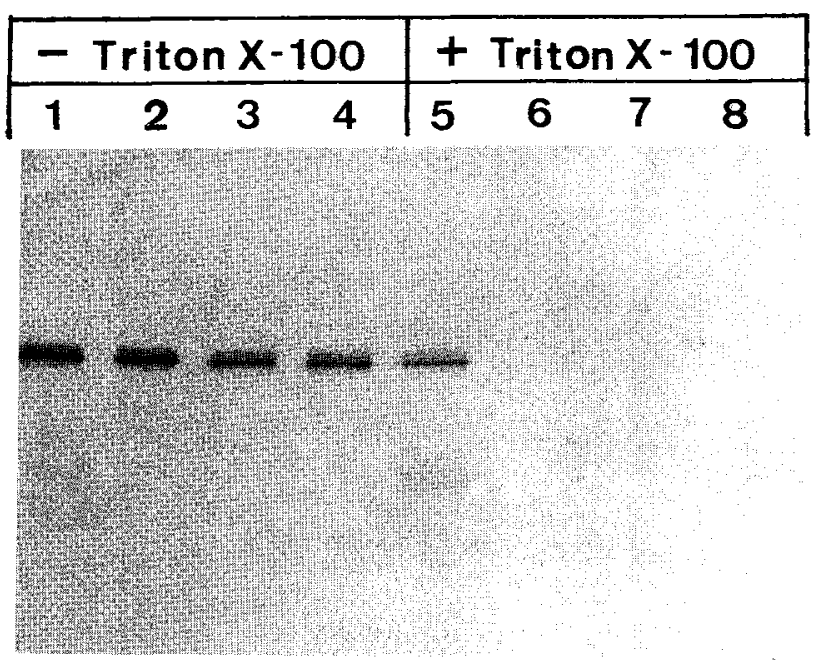

Fig. 7. Digestion of the p138 antigen in microsomal membranes from HeLa cells with trypsin in the presence or absence of Triton X100.

The digestion of the microsomal membrane fractions was performed as described under Materials and Methods. Microsomal membrane fractions were incubated with trypsin at 0 (lanes 1 and 5), 0.03 (lanes 2 and 6), 0.3 (lanes 3 and 7) and $3 \mathrm{mg} / \mathrm{ml}$ (lanes 4 and 8) in the absence (lanes 1-4) or presence (lanes 5-8) of Triton X-100. After the reaction was terminated, the samples were processed by western immunoblot procedure with mAb G3A5. gen was resistant to trypsin digestion in the absence of detergent (lanes 2-4), but upon addition of detergent to the microsomal fraction during digestion, the p138 antigen was no longer resistant to digestion (lanes 6-8). Next, the microsomal fractions were extracted with either $0.5 \mathrm{M} \mathrm{KCl}$ or $0.1 \mathrm{M}$ sodium carbonate, $\mathrm{pH} 11.5$. After centrifugation, the pellet and supernatant fractions were subjected to western immunoblotting procedure. As shown in Figs. 8A and 8B, the p138 antigen remained membrane associated after extraction with either $\mathrm{KCl}$ or sodium carbonate. Since treatment with sodium carbonate causes closed vesicles to convert to open membranes, and causes content proteins and peripheral membrane proteins to be released in soluble forms (36), the p138 antigen was suggested to be an integral Golgi membrane protein.

Separation of the p138 antigen from $\alpha$-D-mannosidase II by ion exchange column chromatography.
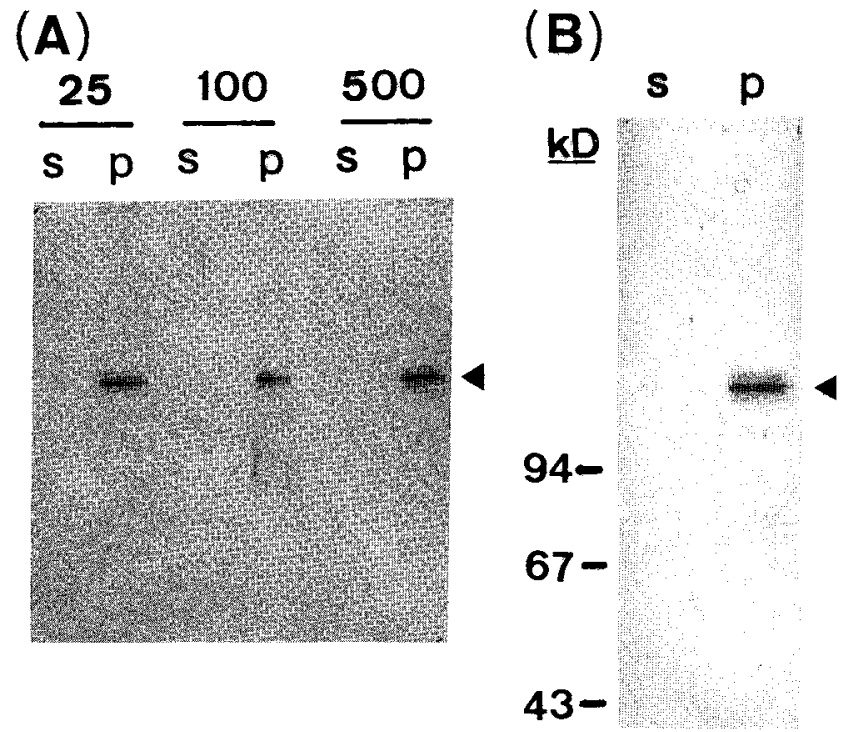

Fig. 8. Effect of $\mathrm{KCl}$ concentration (A) and sodium carbonate treatment (B) on the association of the p138 antigen to microsomal membranes.

(A) The $150,000 \times \mathrm{g}$ pelleted microsomal fractions obtained from $4 \times$ $10^{8} \mathrm{HeLa}$ cells according to the method described by Chicheportiche et al. (39) were resuspended in $0.25 \mathrm{M}$ sucrose, $50 \mathrm{mM}$ Tris- $\mathrm{HCl}, \mathrm{pH}$ $7.3,5 \mathrm{mM} \mathrm{MgCl}_{2}$ containing 25,100 , or $500 \mathrm{mM} \mathrm{KCl}$ and incubated for $15 \mathrm{~min}$ in an ice bath followed by centrifugation at $150,000 \times \mathrm{g}$ for $150 \mathrm{~min}$. The resulting supernatants $(\mathrm{s})$ and pellets $(\mathrm{p})$ were processed using western immunoblotting procedure with mAb G3A5. Arrow head, $138-\mathrm{kDa}$.

(B) The microsomal membrane fraction was resuspended and diluted with $100 \mathrm{mM}$ sodium carbonate, $\mathrm{pH} 11.5$, to bring the protein concentration to $1 \mathrm{mg} / \mathrm{ml}$ as described by Fujiki et al. (36). After incubation for $30 \mathrm{~min}$ in an ice bath, the suspension was centrifuged for $1 \mathrm{~h}$ at $230,000 \times \mathrm{g}, 4^{\circ} \mathrm{C}$. The resulting supernatant (s) and pellet (p) portions were processed using western immunoblot procedure with $\mathrm{mAb}$ G3A5. Arrow head, 138-kDa. 
Data from the flotation in sucrose gradient (Fig. 6) shows that the peak density of Golgi subfractions containing the p138 antigen overlapped with that of $\alpha$-Dmannosidase II. Also, the molecular size of $\alpha$-D-mannosidase II (135-kDa) (16) is close to that of the p138 antigen. The immunopurified p138 antigen lacked $\alpha$-Dmannosidase II activity (data not shown). However, the possibility could not be ruled out that the p138 antigen is indeed $\alpha$-D-mannosidase II since there may have been inactivation of the enzyme during the purification process. To test this possibility, the post-nuclear supernatant was fractionated by chromatography on hydroxylapatite or DEAE-Sephacel columns. The chromatographies were performed using a buffer containing $0.3 \%$ Triton X-100.
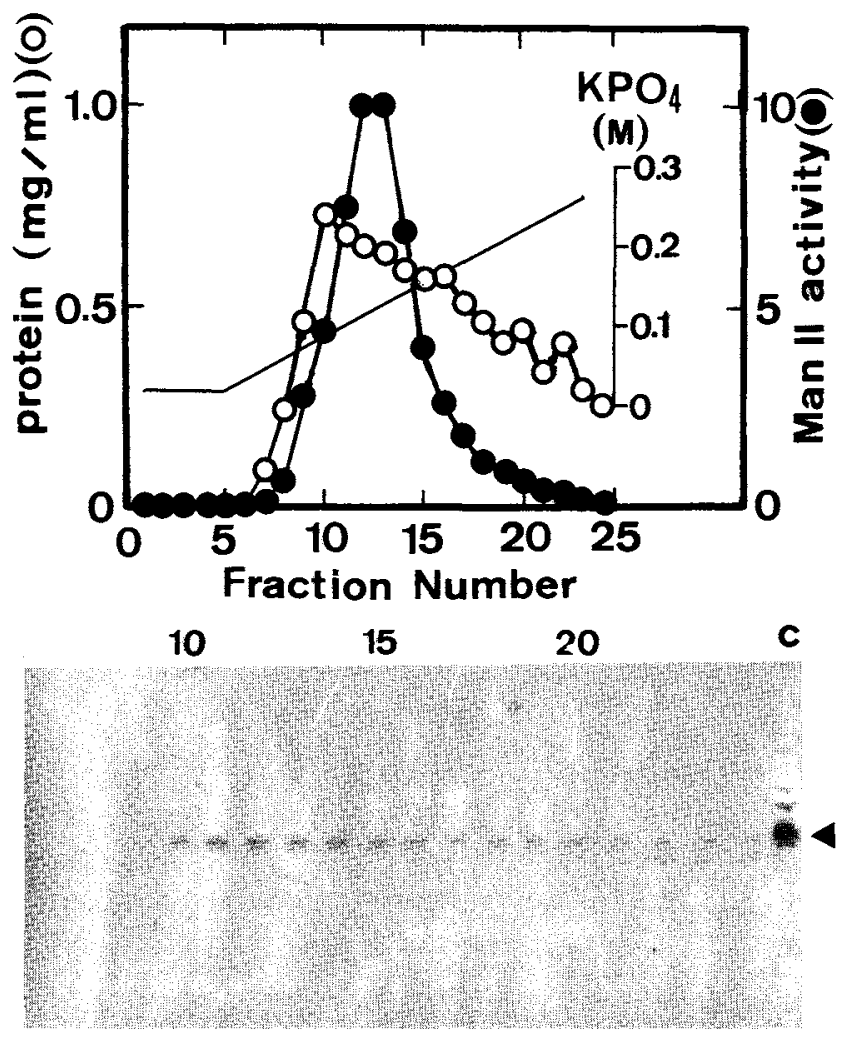

Fig. 9. Chromatography of p138 antigen on a hydroxylapatite column.

The sample prepared as described under Materials and Methods was applied to a hydroxylapatite (BIO-Rad) column $(5 \times 1 \mathrm{~cm})$ equilibrated with buffer D. After washing the column with $20 \mathrm{ml}$ of buffer $D$, it was eluted with a $30 \mathrm{ml}$ linear gradient of $20 \mathrm{mM}$ to $300 \mathrm{mM}$ $\mathrm{KPO}_{4}$ in buffer D. Fractions $(1.3 \mathrm{ml})$ were collected at a flow rate of $10 \mathrm{ml} / \mathrm{h}$. An aliquot $(15 \mu \mathrm{l}$ or $10 \mu \mathrm{l})$ of each fraction was used to measure $\alpha$-D-mannosidase II activity (upper graph) or processed by western immunoblot procedure (lower panel). The buffer concentration was determined by conductivity. Lane $\mathrm{C}$ in western immunoblot was the control sample before chromatography, and the arrow head shows position of $138-\mathrm{kDa}$.
The p138 antigen was eluted from hydroxylapatite column at salt concentration $\left(0.12 \mathrm{M} \mathrm{KPO}_{4}\right)$ comparable with the level of $\alpha$-D-mannosidase II activity (Fig. 9). On the other hand, using DEAE-Sephacel column chromatography the elution of the p138 antigen required a higher concentration of salt $(0.35 \mathrm{M} \mathrm{NaCl})$ than for the elution of $\alpha$-D-mannosidase II activity (Fig. $10)$. Thus, the two proteins were concluded to be different proteins.

Immunoaffinity purification of the p138 antigen. The p138 antigen was purified using immunoaffinity chromatography. Fig. 11 shows the SDS-PAGE of the proteins found retained by the mAb G3A5-immunoaffinity column. The prominent protein band of apparent molecular mass of $138-\mathrm{kDa}$ was shown in lane 1 . As shown in the western immunoblot experiment, the $\mathrm{mAb}$ G3A5 bound to this protein (lane 2). The weakly stained $86 \mathrm{kDa}$ protein band which appeared in immunoblotting was determined to be a degradation product of the p138 antigen, because the amount of $86-\mathrm{kDa}$ pro-
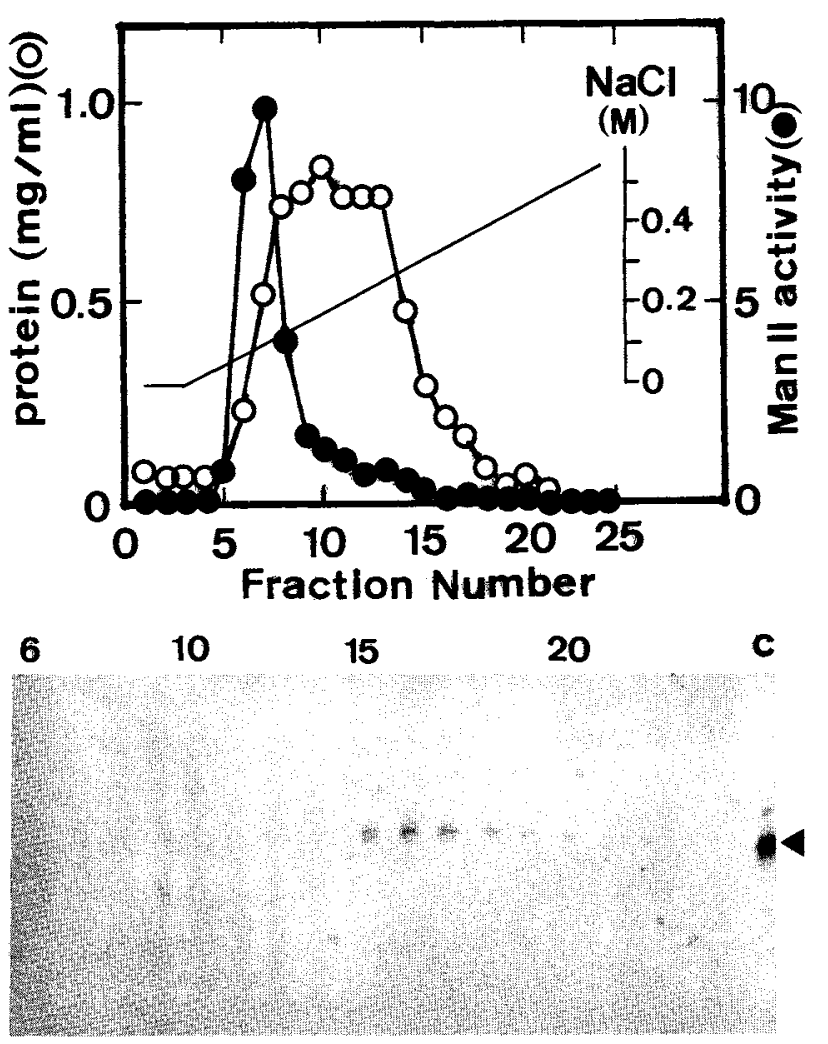

Fig. 10. Chromatography of the p138 antigen on a DEAE-Sephacel column.

The DEAE-Sephacel (Pharmacia) column $(5 \times 1 \mathrm{~cm})$ chromatography of p138 antigen and western immunoblot were performed as described in Fig. 9 legend except that buffer $E$ was used for buffer D. The linear gradient for elution was from $0 \mathrm{mM}$ to $600 \mathrm{mM}$ in $\mathrm{NaCl}$. Lane $\mathrm{C}$ in western immunoblot was the control sample before the chromatography; arrow head shows the position of $138-\mathrm{kDa}$. 


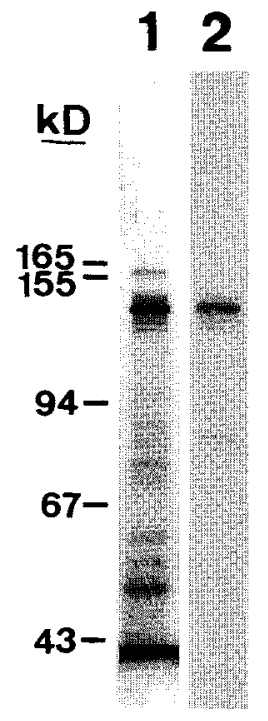

Fig. 11. Isolation of the p138 antigen by immunoaffinity chromatography with mAb G3A5.

Immunoaffinity chromatography was performed as described under Materials and Methods. (Lane 1) SDS PAGE stained by the silver staining method. (Lane 2) Western immunoblot with mAb G3A5.

tein appearing in the immunopurified protein fraction was variable from experiment to experiment.

The p138 antigen contained asparagine-linked carbohydrates. To determine whether the p138 antigen had carbohydrate moieties, proteins purified by affinity chromatography were digested with glycosidases, resolved on a 10\% SDS-PAGE, and subjected to western immunoblot analysis with mAb G3A5. Fig. 12, lane 2 shows the occurrence of two bands with a difference in molecular mass of 2 to $4-\mathrm{kDa}$ after peptide: $\mathrm{N}$-glycosidase $\mathrm{F}$ digestion. The upper one was located at the same position as the original p138 antigen, and the lower one was suggested to be the modified form following removal of asparagine-linked carbohydrates. On the other hand, there was no perceptible change in electrophoretic mobility when the p138 antigen was digested with ENDO F or neuraminidase (data not shown).

\section{DISCUSSION}

An understanding of the molecular organization of the Golgi apparatus could provide insights into the mechanism involved in the sorting and modification of newly synthesized proteins. In the present study, we investigated a novel glycoprotein (p138) present in the Golgi apparatus. Both immunofluorescence double-labeling experiments and the disintegration of the annular appearance of mAb G3A5-Golgi apparatus complex localization following nocodazol treatment proved that the compartment stained with $\mathrm{mAb}$ G3A5 coincided
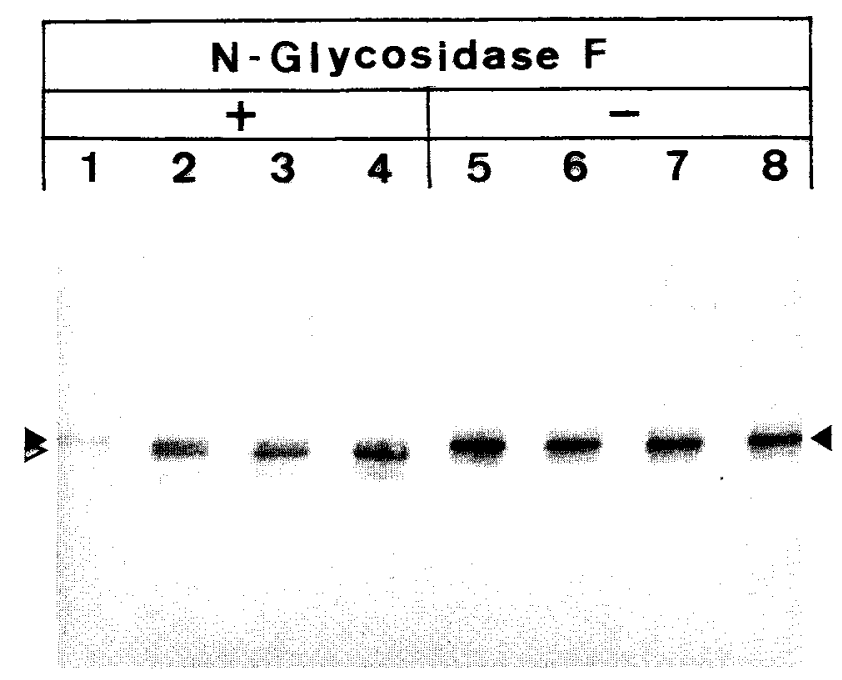

Fig. 12. Effect of peptide: $\mathrm{N}$-glycosidase $\mathrm{F}$ digestion on molecular mass of p138 antigen.

The p138 antigen was isolated by immunoaffinity chromatography. The 138 antigen was preincubated for $5 \mathrm{~min}$ at $50^{\circ} \mathrm{C}$ in $0.05 \mathrm{M}$ Tris$\mathrm{HCl}, \mathrm{pH} 7.5,1 \%$ mercaptoethanol, $0.1 \%$ SDS, and NP-40 (final concentration at $1 \%$ ) was then added. The digestion was performed at $37^{\circ} \mathrm{C}$ for the indicated times after the addition of 0.3 units of peptide: $\mathrm{N}$-glycosidase $\mathrm{F}$ (lanes 1-4). The samples for lanes 5-8 had no peptide: $\mathrm{N}$-glycosidase F. (Lanes 1 and 5) $0 \mathrm{~min}$; (lanes 2 and 6) $30 \mathrm{~min}$; (lanes 3 and 7) $60 \mathrm{~min}$; (lanes 4 and 8) $90 \mathrm{~min}$. The treated samples were processed by western immunoblot procedure with mAb G3A5. The closed and open arrow heads show positions of $138-\mathrm{kDa}$ and $135-$ $\mathrm{kDa}$, respectively.

with that of the Golgi apparatus.

The p138 antigen in microsomes was resistant to digestion with protease or to removal from the membranes by washing with either high concentrations of $\mathrm{KCl}$ or sodium carbonate at $\mathrm{pH} 11.5$. Treatment with BFA for 45 min caused redistribution of $\mathrm{mAb}$ G3A5 staining around the perimeter of the nuclei but short term treatment lacked any effect on distribution, suggesting that the p138 antigen is not a class of surface protein distributed on the Golgi membrane such as has been reported for $\beta$-COP protein (37). From the results obtained by these experiments, we suggested that the p138 antigen must be an integral component of membranes derived from the Golgi fraction. The density of the membrane fraction containing the p138 antigen roughly corresponded with that containing $\alpha$-D-mannosidase II activity. $\alpha$-D-Mannosidase II is a marker protein of medial-Golgi cisternae (34) and Chege and Pfeffer (38) have shown that the trans-Golgi network is not fused with the endoplasmic reticulum upon BFA treatment. BFA treatment did induce redistribution of our p138 antigen, thus localization of p138 antigen to the cis and medial/trans-Golgi cisternae but not to the trans-Golgi network was suggested. 
So far, two other integral membrane proteins of the Golgi apparatus have been reported with molecular masses close to that of $\mathrm{p} 138$ antigen. One is $\alpha$-D-mannosidase II (135-kDa) (16) and the other is GIMP $_{C}(130-$ $\mathrm{kDa}$ (12). The p138 antigen did not show $\alpha$-D-mannosidase II activity nor did it elute at the same salt concentration on DEAE-Sephacel column chromatography. These results indicate that the two proteins are different. GIMP ${ }_{C}$ has been reported to have N-linked complex oligosaccharides and sialic acid (12). The removal of either of these by Endo F or neuraminidase results in a decrease in apparent molecular mass of GIMP $_{C}$ to $118-\mathrm{kDa}$. The p138 antigen is also a glycoprotein with asparagine-linked carbohydrate suggested by decrease in molecular mass after digestion with peptide: $\mathrm{N}$-glycosidase $\mathrm{F}$, although the decrease was only 2 to $4-\mathrm{kDa}$. Unlike GIMP $_{C}$, treatment with Endo $F$ or neuraminidase lacked this effect on p138 antigen. Thus, the p138 antigen is suggested to be different from GIMP $_{C}$, but at present we cannot dismiss the possibility of differing glycosylation of perhaps the same protein in different organisms.

We have purified enough p138 antigen from HeLa cells to begin microsequencing and have obtained partial amino acid sequence data of ten lysyl endopeptidase fragments. Experiments are presently under way to clone the gene for the p138 antigen and to investigate the role of the p138 antigen in the function of Golgi apparatus.

Acknowledgments. This work was supported in part by a Grantin-Aid for Cancer Research from the Ministry of Education, Science and Culture of Japan.

\section{REFERENCES}

1. Meliman, I. and Simons, K. (1992). The Golgi complex: In vitro veritas. Cell, 68: 829-840.

2. Dunphy, W.G. and Rothman, J.E. (1985). Compartmental organization of the Golgi stack. Cell, 42: 13-21.

3. Serafini, T., Stenbeck, G., Brecht, A., Lottspeich, F., ORCI, L., Rothman, J.E., and Wieland, F.T. (1991). A coat subunit of Golgi-derived non-clathrin-coated vesicles with homology to the clathrin-coated vesicle coat protein $\beta$-adaptin. $N a$ ture, 349: 215-220.

4. Burke, B., Griffiths, G., RegGio, H., Louvard, D., and WARREN, G. (1982). A monoclonal antibody against a 135K Golgi membrane protein. EMBO $J, 1: 1621-1628$.

5. GoldFISCHER, S. (1982). The internal reticular apparatus of Camillo Golgi: a complex, heterogeneous organelle enriched in acid, neutral, and alkaline phosphatase, and involved in glycosylation, secretion, membrane flow, lysosome formation, and intracellular digestion. J. Histochem. Cytochem., 30: 717-733.

6. Roth, J. and BERGER, E.G. (1982). Immunochemical localization of galactosyltransferase in HeLa cells: codistribution with thiamine pyrophosphatase in trans Golgi cisternae. J. Cell Biol., 93: $223-229$.

7. Novikoff, P.M., Tulsiani, D.R.P., Touster, O., Yam, A., and Novikoff, A.B. (1983). Immunocytochemical localization of D-mannosidase II in the Golgi apparatus of rat liver. Proc. Natl. Acad. Sci. USA., 80: 4364-4368.

8. Smith, Z.D.J., Gumkowski, F.D., Yanagisawa, K., and JAMIESON, J.D. (1984). Endogeneous and monoclonal antibodies to the rat pancreatic acinar cell Golgi complex. $J$. Cell Biol., 98: 2035-2046.

9. Dunphy, W.G., Brands, R., and Rothman, J.E. (1985). Attachment of terminal $\mathrm{N}$-acetylglucosamine to asparagine-linked oligosaccharides occurs in central cisternae of the Golgi stack. Cell, 40: 463-472.

10. Brown, W.J. and Farquhar, M.G. (1987). The distribution of 215-kilodalton mannose-6-phosphate receptor within cis (heavy) and trans (light) Golgi subfractions varies in different cell types. Proc. Natl. Acad. Sci. USA., 84: 9001-9005.

11. Saraste, J., Palade, G.E., and Farquhar, M.G. (1987). Antibodies to rat pancreas Golgi subfractions: identification of a 58-kd cis-Golgi protein. J. Cell Biol., 105: 2021-2029.

12. Yuan, L., BarRIOCANAL, J.G., Bonifacino, J.S., and Sandoval, I.V. (1987). Two integral membrane proteins located in the cis-middle and trans-part of the Golgi system acquire sialylated $\mathrm{N}$-linked carbohydrates and display different turnovers and sensitivity to cAMP-dependent phospholylation. J. Cell Biol., 105: 215-227.

13. Taatjes, D.J., Roth, J., Weinstein, J., and Paulson, J.C. (1988). Post-Golgi apparatus localization and regional expression of rat intestinal sialyltransferase detected by immunoelectron microscopy with polypeptide epitope-purified antibody. $J$. Biol. Chem., 263: 6302-6309.

14. Angeletti, R.H., Xu, R., Gonatas, J.O., Stieber, A., and GonATAS, N.K. (1989). Identification of a novel protein (G210) specific to the Golgi apparatus. J. Histochem. Cytochem., 37: $1177-1182$.

15. Gonatas, J.O., Mezitis, S.G.E., Stieber, A., Fleischer, B., and Gonatas, N.K. (1989). MG-160: a novel sialo-glycoprotein of the medial cisternae of the Golgi apparatus. J. Biol. Chem., 264: 646-653.

16. Baron, M.D. ANd GarofF, H. (1990). Mannosidase II and the 135-kDa Golgi-specific antigen recognized by monoclonal antibody 53FC3 are the same dimeric protein. J. Biol. Chem., 265: 19928-19931.

17. Yagura, T., Tanaka, S., Kozu, T., Seno, T., and Korn, D. (1983). Tight association of DNA primase with a subspecies of mouse DNA polymerase $\alpha$. J. Biol. Chem., 258: 6698-6700.

18. KozU, T., Nikaido, K., and Yagura, T. (1990). Structure of DNA polymerase $\alpha$-primase complexes from mammalian cells analyzed by using monoclonal antibodies. J. Biochem., 107: 536-538.

19. Tulsiani, D.R.P., Opheim, D.J., and Touster, O. (1977). Purification and characterization of a $\alpha$-D-mannosidase from rat liver golgi membranes. J. Biol. Chem., 252: 3227-3233.

20. Bhavanadan, V.P. and Davidson, E.A. (1976). Characteristics of a mucin-type sialoglycopeptide produced by B16 mouse melanoma cells. Biochem. Biophys. Res. Commun., 70: 139145.

21. Elder, J.H. and AleXander, S. (1982). Endo- $\beta$-N-Acetyl-glucosaminidase F: Endoglycosidase from Flavobacterium meningosepticum that cleaves both high-mannose and complex glycoproteins. Proc. Natl. Acad. Sci. USA., 79: 4540-4544.

22. Natowicz, M., Baenziger, J.U., and Sty, W.S. (1982). Structural studies of the phosphorylated high mannose-type oligo-saccharides on human $\beta$ glucuronidase. J. Biol. Chem., 257: 44124420 . 
23. Tulsiani, D.R.P., Hubbard, S.C., RobBins, P.W., and TOUSTER, O. (1982). $\alpha$-D-Mannosidases of rat liver golgi membranes. Mannosidase II is the GlcNAcMan ${ }_{5}$-cleaving enzyme in glycoprotein biosynthesis and mannosidases IA and IB are the enzymes converting $\mathrm{Man}_{9}$ precursors to $\mathrm{Man}_{5}$-intermediates. $J$. Biol. Chem., 257: 3660-3668.

24. Beams, H.W. and Kessel, R.G. (1968). The Golgi apparatus: structure and function. Int. Rev. Cytol., 23: 209-276.

25. Whaley, W.G. and Dauwalder, M. (1979). The Golgi apparatus. The plasma membrane, and functional integration. In. Rev. Cytol., 58: 199-245.

26. Fujiwara, T., Oda, K., Yokota, S., Takatsuki, A., and IKEHARA, Y. (1988). Brefeldin A causes disassembly of the golgi complex and accumulation of secretory proteins in the endoplasmic reticulum. J. Biol. Chem., 263: 18545-18552.

27. Domes, R.W., Russ, G., and Yewdell, J.W. (1989). Brefeldin $A$ redistributes resident and itinerant Golgi proteins to the endoplasmic reticulum. $J$. Cell Biol., 109: 61-72.

28. Lippincott-Schwartz, J., Yuan, L.C., Bonifacino, J.S., and KIAUSNER, R.D. (1989). Rapid redistribution of Golgi proteins into the ER in cells treated with brefeldin A: evidence for membrane cycling from Golgi to ER. Cell, 56: 801-813.

29. Lippencott-Schwart, J., Donaldson, J.G., Schweizer, A., Berger, E.G., Hauri, H.P., Yuan, L.C., and Klausner, D. (1990). Microtubule-dependent retrograde transport of proteins into the ER in the presence of brefeldin A suggests an ER recycling pathway. Cell, 60: 821-836.

30. Misumi, Y., Miki, K., Takahashi, A., Tamura, G., and IKEHARA, Y. (1986). Novel blockade by brefeldin A of intracellular transport of secretory proteins in cultured rat hepatocytes. J. Biol. Chem., 261: 11398-11403.

31. Oda, K., Hirose, S., Takami, N., Misumi, A., Takatsuki, A., and IKeHARA, Y. (1987). Brefeldin A arrests the intracellular transport of a precursor of complement $\mathrm{C} 3$ before its conver- sion site in rat hepatocytes. FEBS Lett., 214: 135-138.

32. De Brabander, M.J., Von de Veire, R.M.L., Aerts, F.E.M., BORGERS, M., and JANSSEN, P.N.J. (1976). The effects of methyl S(2-thienylcarbonyl)H-benzimidazolyl-2-carbamate, a new antitumoral drug interfering with microtubules, on mammalian cells cultured in vitro. Cancer Res., 36: 905-916.

33. Allan, V.J. and Kreis, T.E. (1986). A microtubule-binding protein associated with membranes of the Golgi apparatus. $J$. Cell Biol., 103: 2229-2239.

34. GoldBerg, D.E. and KornFeld, S. (1983). Evidence for extensive subcellular organization of asparagine-linked oligosaccharide processing and lysosomal enzyme phosphorylation. J. Biol. Chem., 258: 3159-3165.

35. Scheele, G.A., Palade, G.E., and Tartakoff, A.M. (1978). Cell fractionation studies on the guinea pig pancreas: redistribution of exocrine proteins during tissue homogenization. $J$. Cell Biol., 78: 110-130.

36. Fujiki, Y., Hubbard, A., Fowler, S., and Lazarow, P.B. (1982). Isolation of intracellular membranes by means of sodium carbonate treatment: application to endoplasmic reticulum. J. Cell Biol., 93: 97-102.

37. Donaldson, J.G., Schwartz, J.L., Bloom, G.S., Kreis, T.E., and Klausner, R.D. (1990). Dissociation of a 110-kD peripheral membrane protein from the Golgi apparatus is an early event in brefeldin A action. J. Cell Biol., 111: 2295-2306.

38. Chege, N.W. and Preffer, S.R. (1990). Compartmentation of the Golgi complex: Brefeldin-A distinguishes trans-Golgi cisternae from the trans-Golgi network. J. Cell Biol., 111: 893899.

39. Chicheportiche, Y., Vassalli, P., and Tartakoff, A.M. (1984). Characterization of cytoplasmically oriented Golgi proteins with monoclonal antibody. J. Cell Biol., 99: 22002210.

(Received for publication, April 28, 1992

and in revised form, June 1, 1992) 